18. Prokofiev, S. (2002). Diaries 1918-1933. S. Prokofiev (Ed.). Paris: DIAKOM [in Russian].

19. Prokofiev, S. (1961). Materials, documents, memories. Second edition. S. Shlyfshtein (Ed.). Moscow: Gosudarstvennoe Muzykalnoe Izdatielstvo [in Russian].

20. Prokofiev, S. (1991). Articles, interviews. Moscow: Sovetskyi Kompozytor [in Russian].

21. Safonova, T. (2009). Oeuvre of S. Prokofiev: analysis of methaphysical component. $\mathrm{PhD}$ thesis. National Sobinov academy of music. Saratov [in Russian].

22. Kholopov, Yu. (1972). Oeuvre of S. Prokofiev in modern academic musicology. Moscow: Muzyka [in Russian].

23. Ivashkin, A. (1994). Word about Prokofiev. In: Conversations with A. Shnitke. Moscow: RIK Kultura [in Russian].

УДК 78.034:78.071 Монтеверді

DOI: https://doi.org/10.33643/kmus.2019.59.10

$$
\begin{array}{r}
\text { Вероніка Пкшкова, } \\
\text { аспірант кафедри історії світової музики } \\
\text { Національної музичної академії України ім. П. I. Чайковського } \\
\text { https://orcid.org/0000-0001-7875-2489 } \\
\text { veronika_peshova@ukr.net } \\
\text { Veronika Pieshkova, } \\
\text { Postgraduate at the Department of History of World Music, } \\
\text { Ukrainian National Tchaikovsky Academy of Music } \\
\text { https://orcid.org/0000-0001-7875-2489 } \\
\text { veronika_peshova@ukr.net }
\end{array}
$$

\title{
ПРИНЦИПИ РОБОТИ 3 ПОЕТИЧНИМ ТЕКСТОМ У РАННІХ МАДРИГАЛАХ КЛАУДІО МОНТЕВЕРДІ (НА ПРИКЛАДІ МАДРИГАЛІВ ІЗ ПЕРШИХ ЧОТИРЬОХ КНИГ КОМПОЗИТОРА)
}

У статті розглянуто мадригали 3 перших чотирьох Книг Клаудіо Монтеверді. Визначено специфіку образно-емоційної сфери, виявлено принципи втілення поетичного тексту в музичній тканині мадригалів. Здійснено підрядковий переклад українською мовою мадригалів «La vaga pastorella» 3 Першої книги (1587), «Non si levav'ancor» із Другої книги (1590), «Sovra tenere erbette» 3 Третьої книги (1592), «A un giro sol de, bell'occhi lucenti» з Четвертої книги (1603). На основі аналізу перелічених творів прослідковано процес зміни тематики поетичних текстів від Першої до Четвертої книг мадригалів Клаудіо Монтеверді.

Ключові слова: мадригал, слово, афект, бароко, втілення поетичного тексту, Монтеверді. 
Pieshkova Veronika. Principles of working with poetic text in the early madrigals by Claudio Monteverdi (on the basis of madrigals from the first four Books by the composer). Baroque music in our time is played on leading European scenes, recorded in the most quality musical studios and released under authoritative labels. The relevance of the study is to appeal to the work of the eminent figure of this time, the Italian composer of the second half of the XVI - the first half of the XVII century, Claudio Monteverdi, in connection with the practical interest in the music of the Baroque era. Main objective of the study is to determine the figurative-emotional sphere and to identify the principles of the embodiment of poetic text in the madrigals of the first four books. Methodology. During the study, methods of structural, intonational analysis and a comparative method for revealing the specifics of working with poetic text in the first four books of madrigal Monteverdi and the comparison of their figurative and emotional sphere were used.

Research results. In the First Book of the madrigals the pastoral atmosphere prevails, the growth of technique of work with polyphony has been demonstrated in the madrigals. In the Second Book of madrigals, the composer actively applies the principle of reprisal. The second book makes a new emphasis on the content of poetry texts placed on music, and the extremely flexible concept of polyphonic design, which will lead directly to the main elements of the musical idiom of the Baroque. The main theme of the Third Book of the composer's madrigals is love, when it becomes a source of pain because of not mutual feelings, betrayals or exquisite descriptions of sensual scenes. The Monteverdi's Third Book of the madrigals is marked by the expansion of the emotional sphere. The greatest achievement of the Fourth Book is the enormous power of emotional tension, which is achieved through the use of dissonances and chromatism.

Conclusion. From the First to the Fourth Book of the madrigals by Monteverdi, the themes of poetic texts changed: from the pastoral atmosphere of the First Book, the themes of nature in the Second, emotionally-intensive imagery of the Third to the experience of pain, the suffering of the Fourth Book. The means of their embodiment in musical texture were developed: from polyphonic presentation of voices to expressive melodies in a transparent texture in combination with modern composers and harmonies.

Key words: madrigal, word, affect, baroque, embodiment of poetic text, Monteverdi.

Пешкова Вероника. Принципы работы с поэтическим текстом в ранних мадригалах Клаудио Монтеверди (на примере мадригалов из первых четырех Книг композитора). Музыка барокко в наше время исполняется на ведущих европейских сценах, записывается в самых 
качественных музыкальных студиях и выпускается под авторитетными лейблами. В связи с практическим интересом к музыке эпохи барокко, актуальность исследования заключается в обращении к творчеству выдающегося деятеля этого времени, итальянского композитора второй половины XVI - первой половины XVII веков Клаудио Монтеверди. Основная цель исследования - определить специфику образноэмоциональной сферы и выявить принципы воплощения поэтического текста в мадригалах первых четырех Книг. Методология. В ходе исследования были использованы методы структурного, интонационного анализа и компаративный метод - при выявлении особенностей работы с поэтическим текстом в первых четырех Книгах мадригалов Монтеверди и сравнении их образно-эмоциональной сферы.

Результаты исследования. В Первой книге мадригалов преобладает пасторальная атмосфера, в мадригалах продемонстрирован совершенствование техники работы с многоголосием. Во Второй книге мадригалов композитор активно применяет принцип репризности. Вторая книга делает новый акцент на содержании поэтических текстов и чрезвычайно гибкой концепции полифонической конструкции, которая приведет непосредственно к основным элементам музыкальной идиомы барокко. Главная тема Третьей книги мадригалов композитора - любовь, когда она становится источником боли из-за невзаимных чувств и предательств. Третья книга мадригалов К. Монтеверди отмечена расширением эмоциональной сферы. Величайшим достижением Четвертой книги является огромная сила эмоционального напряжения, которое достигается благодаря применению диссонансов и хроматизмов.

Заключение. От Первой к Четвертой книге мадригалов Монтеверди менялись темы поэтических текстов: от пасторальной атмосферы Первой книги, темы природы во Второй, эмоционально-напряженных образов Третьей до переживания боли, страдания в Четвертой книге. Разработаны средства их воплощения в музыкальной ткани: от полифонического представления голосов до выразительных мелодий в прозрачной фактуре в сочетании с современными композитору гармониями.

Ключевые слова: мадригал, слово, аффект, барокко, воплощение поэтического текста, Монтеверди.

Музика епохи Бароко в наш час лунає на провідних європейських сценах, записується у найякісніших музичних студіях і виходить у світ під авторитетними лейблами. Вишукані твори композиторів цієї епохи 
захоплюють і вражають слухачів своїм широким спектром емоцій та «головними героями» мистецтва бароко - афектами.

У зв'язку з практичним зацікавленням музикою епохи Бароко $є$ актуальним звернення до творчості видатної постаті цього часу італійського композитора другої половини XVI - першої половини XVII століть Клаудіо Монтеверді.

У творчості К. Монтеверді визначальну роль відіграє слово, адже у своїй музиці композитор прагне розкрити зміст й інтонації, які закладено в ньому. «Усуньте слово, - писав Монтеверді, - i, як тінь без душі, музика втратить найбільш істотну свою приналежність» [5, с. 120]. Тому він приділяє увагу одному з ключових жанрів епохи - жанру мадригалу, що побудований на слові.

У творчості композитора жанр мадригалу пройшов великий еволюційний шлях від ранніх мадригалів типу канцонет до цілих театралізованих сцен. Цю еволюцію було зафіксовано у восьми книгах мадригалів композитора (1587-1638).

Зміни в жанрі мадригалу у творчості композитора відбувався поступово. Вісім книг мадригалів Монтеверді умовно можна поділити на дві групи:

- перші п’ять книг мадригалів (1587, 1590, 1592, 1603, 1605 років), створені до роботи над оперою «Орфей»;

- VI, VII і VIII книги мадригалів $(1614,1619,1638)$, створені після написання «Орфея».

Першу групу можемо також розділити на дві підгрупи: три книги мадригалів, які видано до закордонних подорожей композитора з герцогом Вінченцо Гонзага, та IV i V книги, видані після подорожей ${ }^{1}$. Така диференціація першої групи зумовлена акцентуванням нашої уваги на тому факті, що період «мадригального мовчання» композитора між Третьою та Четвертою книгами сприяв значному зростанню майстерності К. Монтеверді.

Мета дослідження полягає у визначенні образно-емоційної сфери та виявленні принципів втілення поетичного тексту в мадригалах перших чотирьох книг. Під час дослідження застосовувалися методи структурного, інтонаційного аналізу, а також компаративний метод - для виявлення специфіки роботи з поетичним текстом у перших чотирьох книгах мадригалів Клаудіо Монтеверді та для порівняння їхньої образно-емоційної сфери.

Новизну для українського музикознавства становить звернення до мадригалів із перших чотирьох Книг Клаудіо Монтеверді, адже творчість композитора вивчається у вітчизняному музикознавчому просторі дуже

\footnotetext{
${ }^{1}$ Четверту книгу мадригалів було видано через одинадцять років після Третьої.
} 
побіжно: мадригальна спадщина композитора досліджується у статті В. Жаркової [2], окремі мадригали Монтеверді представлені в дисертації Н. Даньшиної [1] Також новизна дослідження полягає в здійсненому вперше підрядковому перекладі з італійської мови на українську текстів мадригалів «La vaga pastorella» («Симпатична пастушка») з Першої книги (1587 року), «Non si levav'ancor» («Новий світанок все ще не піднімався») 3 Другої книги (1590 року), «Sovra tenere erbette» («Серед м'яких трав») із Третьої книги (1592 року), «A un giro sol de' bell'occhi lucenti» («В колі поглядів цих красивих яскравих очей») із Четвертої книги (1603 року).

У мадригалах, що побачили світ перед створенням композитором його опер, Клаудіо Монтеверді поєднує різні традиції: класична мадригальна манера (п'ять вокальних партій a cappella) розширюється і поліфонічне письмо поєднується з акордовим, дисонанси підкреслюють експресію слова.

У період створення Першої книги мадригалів композитора слухачі шанували елегантну, витончену музику. Тому в Першій книзі мадригалів для п'яти голосів (1587), яку було видано у Венеції Ріккардо Амадіно, панує пасторальна атмосфера й відчутні впливи попередників К. Монтеверді - Луки Маренціо, Ж’яша де Верта, Андреа Габріелі. У порівнянні 3 першими творами композитора (його канцонетами, що вийшли в світ за три роки до Першої книги мадригалів $\left.{ }^{1}\right)$, у мадригалах продемонстровано вдосконалення техніки роботи з багатоголоссям [10].

Мадригал «La vaga pastorella» («Симпатична пастушка») - один із шедеврів цієї збірки.

$$
\begin{gathered}
\text { Симпатична пастушка } \\
\text { Йде між квітами й травами } \\
\text { Співаю ніжно я зітхаю } \\
\text { Що я бачу ії такою красивою, } \\
\text { І обтяжену стражданнями } \\
\text { Все ж я йду за нею. } \\
\text { Ах, пастушко моя, } \\
\text { прошу тебе, не втікай. }
\end{gathered}
$$

Весь мадригал будується на ритмі музичного матеріалу, використаного у вступній фразі. Він починається канонічною імітацією зі слабкої долі, що зображає пастушку, блукаючу в квітковому полі. Потім музика сповільнюється й відкрита «солодкість» початку розсіюється (тт. 1-21).

Тут К. Монтеверді використовує метод накладення двох контрастних текстових і музичних фраз (тт. 22-29): фраза «е carco di martiro» («i

\footnotetext{
${ }^{1}$ Перші твори композитора розглядає у своєму дослідженні «Claudio Monteverdi: Sacrae Cantiunculae; Madrigali Spirituali, Canzonette a 3 Voci» Ентоні Прайєр [14].
} 
навантажену стражданнями») спускається важко на довгих нотах, а «la seguo tuttavia» («все ж я йду за нею») швидко переміщається за допомогою стрибків у мелодії та переходить у фразу «ti prego non fuggire» («прошу тебе, не втікай» - тт. 57-60) - епізод перед драматичним і виразним фіналом.

Другу книгу мадригалів (1590) було опубліковано у Венеції видавцем Анджело Гардано. Це видання, як зазначає Гері Томлінсон, К. Монтеверді присвячує Джакомо Рікардо - президенту Сенату й Ради Його Католицької Величності у Мілані [16, с. 45].

Поетичні образи Другої книги висвітлюють дві теми, що особливо поширені в придворній культурі: кохання й природа. Тема кохання вже оспівувалася К. Монтеверді й музичною культурою того часу. Тема природи - яскравої, солодкої, палаючої - пропонує композиторові широкий простір для музичних втілень і відповідного звукового відтворення.

Мадригали Другої книги К. Монтеверді (так само, як і Першої) за стилем близькі до канцонет. Поруч із цим, композитор активно застосовує принцип репризності [3]. Музикознавець Валентина Конен пише, що «тут гармонія виникає вже не як “побічний продукт" поліфонічних нашарувань, a як самостійний цілеспрямований ефект, як найважливіший елемент музичної структури» [3, с. 111].

Дев'ять мадригалів Книги створено на тексти відомого італійського поета Торквато Тассо, що дають величезний стимул композиторській уяві. Саме Тассо (як стає відомо 3 передмови до Восьмої книги мадригалів) надихнув К. Монтеверді на пошуки нового художнього стилю в музиці.

Мадригал «Non si levav'ancor» на слова Торквато Тассо $є$ одним із найвідоміших творів не тільки цієї книги, а й мадригального репертуару в західноєвропейському просторі. Він складається 3 двох частин. Перша частина «Non si levava ancor l'alba novella» («Новий світанок все ще не піднімався») починається м'яко, описуючи ще сплячу природу, де зображено пейзажі світанку, які ще не відбулися: птахів, все ще «замкнених у гніздах», і присутності мерехтливого світла зірки Венери. Головні герої ховаються, коханці повинні розлучитися після щасливої ночі, проведеної разом. З'являється тисяча контрастних спалахів: поцілунки, сльози й зітхання.

Світанок ще не піднявся, і птахи не потягнули крила до нового сонця, але все ще палає кохання зірка коли два чесних і витончених закоханих, з якими весела ніч об'єдналася 
як Акант ${ }^{1}$, у стількох вигинах і поворотах, були розлучені новим світлом; солодкі крики

у фінальних обіймах

змішані з поцілунками й зітханнями, тисяча палаючих думок, тисяча прагнень.

Тисяча невиконаних бажань

у тих вогнях неясних

розкрийте цю душу закохану, $\mathrm{i}$ ту.

Ці образи в другій частині «E dicea l’una sospiranda» («I один сказав, зітхаючи») переходять все більше в тему життя у стражданні: природа насправді прокидається, засуджуючи розставання, яке для двох закоханих дорівнює смерті.

І один сказав, зітхаючи:

«Душа, о Господи» млявими словами.

I інший відповів: «Моє життя, о Господи».

«О Господи, ні, залишися!» I вони не підуть

перед новим сонцем.

I перед світанком, який піднявся в небо, кожен бачив

найкрасивіші троянди

на блідих, люблячих губах,

і очі мерехтять, як невелике полум'я.

I їхнє прощання було для душ

які розділяються й вириваються:

«До побачення, тому що я йду і помру».

Солодка знемога й меланхолійний відхід.

Зосередимо увагу на втіленні фрази «апima, a Dio» («душа, о Господи») у другій частині мадригалу (тт. 6-12). Цілий рядок поетичного тексту К. Монтеверді розділяє та виокремлює вигук «a Dio», який імітаційно проводить у всіх п'яти голосах. Композитор підкреслює промовляння до Господа, посилюючи драматичний ефект повтореннями. Такий метод розробки матеріалу - метод повтору - композитор використовує також у фразі «Vita, a Dio» («життя, о Господи») (тт. 23-25), та «a Dio, rimanti!» («О Господи, залишися!») (тт. 27-30).

Витончено збалансована, багатобарвна друга частина «E dicea l'una sospiranda» в цілому представляє твір поліфонії епохи Відродження, у якій увага приділяється якості тексту, але структура частини - вже

\footnotetext{
${ }^{1}$ Акант - декоративний орнамент, що характерний для мистецтва античності. Має в основі малюнок рослини аканту.
} 
бароко. Це означає, що поліфонія більше підпорядкована гармонічній логіці. Значну частину твору побудовано на акордовому викладі, у верхніх голосах якого утворюється мелодична лінія. Таким чином, можемо спостерігати ознаки гомофонно-гармонічної фактури, де 3'являється мелодична лінія з гармонічною підтримкою.

На думку музикознавця Лоренцо Б'янконі, у цьому мадригалі існує тенденція до мініатюрності, яка проявляється у групуванні голосів, виділенні дрібних деталей кольору й світла [11].

Відмінності між Другою та Першою книгами напевно пояснюються тим, що увагу К. Монтеверді привернули деякі 3 мадригалів капельмейстера придворної капели в Базиліці Святої Барбари Ж'яша де Верта, а саме - його Восьма книга мадригалів для п'яти голосів, видана 1586 року. Музикознавці В. Конен [3] і Д. Арнольд [10] відзначали певну схожість стилю Другої книги мадригалів К. Монтеверді та збірки п'ятиголосних мадригалів Ж'яша де Верта. I це не випадково - Верт був хорошим другом Т. Тассо й використовував багато його поезій.

Перша й Друга книги мадригалів 1587 і 1590 років свідчать про те, що майже в 20-річному віці К. Монтеверді вже досяг високого рівня композиційної зрілості й розробляв свій особливий і оригінальний стиль, який пізніше буде характеризувати творчість композитора.

Зокрема, Друга книга робить новий акцент на змісті поетичних текстів, покладених на музику, i надзвичайно гнучкій концепції поліфонічної конструкції, яка приведе безпосередньо до основних елементів музичної ідіоми бароко: декламаційного, монодичного та схвильованого стилів (concitato).

Третя книга мадригалів композитора (1592), опублікована у Венеції видавцем Річчардо Амадіно та присвячена герцогу Вінченцо Гонзага, вже була високо оцінена сучасниками.

При виборі текстів для мадригалів цієї книги К. Монтеверді звертається до творчості поета Джамбаттісто Гваріні (автора одного 3 найвідоміших текстів епохи Відродження «Il pastor fido» 1589 року), який у той час відвідував Мантую (адже любов герцога до мистецтва сприяла контактам Мантуї 3 авторитетними митцями епохи). А «божественний» ${ }^{1}$ Т. Тассо (до якого звертався раніше) представлений тільки трьома строфами 3 16-ї та 12-ї пісень поеми «Звільнений Єрусалим». Це свідчить про перехід до емоційно-напруженої образної сфери в мадригалах. Дж. Гваріні привернув увагу К. Монтеверді своїм трактуванням людських взаємовідносин.

\footnotetext{
${ }^{1}$ Так сам К. Монтеверді називав поета [9].
} 
Основною темою Третьої книги мадригалів композитора $є$ любов, що стає джерелом болю через невзаємні почуття, зраду, або представлена вишуканими описами чуттєвих сцен, як у мадригалі «Sovra tenere erbette» («Серед м’яких трав»). Мадригал створено в «легкому» стилі канцонети - зі жвавими ритмами й повторюваними розділами. Поетичний текст складається з дванадцяти рядків, які можна поділити на чотири терцини, що утворюють чотири розділи мадригалу: перший розділ - тт. 1-12; другий розділ - тт. 12-36; третій розділ - тт. 37-56, четвертий розділ - тт. 56-89.

Перший розділ (тт. 1-12) складається 3 трьох епізодів, кожен 3 яких відповідає одному рядку поетичного тексту. Вступ добре відображає для ідилічної пасторальної атмосфери тексту:

Серед м'яких трав і білих квітів

Сиділа Філлі

У тіні лаврового дерева

Мадригал починається спокійним рухом трьох голосів (soprano I, soprano II, tenore): мажорним тризвуком у гармонічному викладі в першому такті та паралельними терціями сопрано у тт. $2-3$, тимчасом як партія тенора після октавного стрибка рухається у протилежному від сопрано низхідному напрямку. Багато в чому атмосферу мрійливості створено завдяки відсутності басу, що полегшує фактуру.

Другий рядок поетичного тексту (тт. 4-9) характеризується подвійним каноном, який переходить у третій рядок тексту в гармонічному викладі.

У другому розділі рядок поетичного тексту (тт. 12-36) чітко поділений на дві частини знаком пунктуації «двокрапка». У тт. 12-15 два піввірші присутні одночасно в чотирьох із п'яти голосів (canto, quinto, alto, tenore): це дуже важливо відносно новизни цього мадригалу, оскільки відбувається дроблення поетичного вираження, яке переводить від однієї частини до іншої.

Коли я сказав їй: дорога Філлі, я вмираю!

І вона повернулася до мене,

Сором'язливе обличчя.

Третій розділ (тт. 37-56), являє собою розробку всього тематичного матеріалу, який зустрічався в мадригалі.

Я застиг, ослаблений від червоної посмішки,

Що від радості серця

Я вірю в благословіння Любові.

Прийом дроблення поетичного тексту між голосами використовується тут більш інтенсивно, ніж у попередньому розділі. Значним є перш за все драматичний ефект посилення звукової потужності слова «frenò («застиг»), 
що виконується басом у 37 такті. У цьому розділі К. Монтеверді використовує більшість мелодичних фрагментів, які вже лунали й розробляє ïx у музичній тканині за допомогою імітацій у всіх голосах.

У четвертому розділі (тт. 56-71), повертається симетрія: перший епізод (тт. 56-60) відновлює паралельний рух, але посилюючи його розділенням на дві групи, що утворені soprano II і tenore 3 одного боку, і soprano $I$ та alto - 3 іншого, тимчасом як бас виконує функцію своєрідного cantus firmus:

Вона з радістю сказала мені:

«Поцілуй мене, Тірсо мій, адже від бажання, відчуваю, вмираю і я».

Музичні засоби, використані композитором у цій Книзі, мають вплив Вертівської декламаційної техніки. Деякі починаються декламованим словом соло (наприклад, «Se per estremo ardore»).

Третя книга мадригалів Монтеверді знаменується розширенням емоційної сфери. До Книги, разом із декламаційними мелодіями та хроматизмами, повернулися й дисонуючі пасажі. Вони вже не такі «в'язкі», як у Першій книзі, але тепер набагато дієвіші. Як зазначає Д. Арнольд, «із розширенням емоційної сфери ці вираження емоцій болю більше не здаються перебільшеними» [10, с. 56].

Третю книгу було тричі перевидано (1594, 1598 та 1600 роки перевидання), що свідчить про успіх молодого композитора, твори якого раніше не були достатньо популярними.

Шлях до видання Четвертої книги мадригалів К. Монтеверді тривав довгих одинадцять років. За цей час композитор супроводжував герцога Гонзагу в його подорожах і походах. Перебування в різних країнах і знайомство з культурним життям поза Італією сприяло надзвичайному розширенню музичних вражень та знань композитора. К. Монтеверді відвідав Австрію, Угорщину та Фландрію, а також за цей час він доторкнувся до новітньої французької вокальної та балетної музики.

Четверту книгу мадригалів було опубліковано (так само, як і Третю) у Венеції видавцем Рікардо Амадіно 1603 року. Дослідник Д. Арнольд вважає, що ця Книга ймовірно найбільш вишукана й змістовна з усіх, що це робота вже сформованого майстра $[10$, с. 59]. Найбільшим досягненням цієї книги можемо назвати величезну силу напруги, яку дисонанси й хроматизми надають номерам з образами глибокого смутку.

У Четвертій книзі К. Монтеверді слідує образам та почуттям поетичних текстів кожного мадригалу більш точно в порівнянні 3 попередніми Книгами мадригалів. 
Мадригал «A un giro sol de 'bell'occhi lucenti» («У колі погляду цих красивих яскравих очей») на текст Джованні Гваріні - це зразок пізнього ренесансного вокального стилю К. Монтеверді, тут присутні розвинена орнаментика в мелодії та багаті виразні дисонанси. Контраст між високими й низькими голосами відрізняе фактуру мадригалу від змішаної фактури вокальної поліфонії Високого Ренесансу.

Цей твір будується 3 куплетів, у кожному 3 яких проявляється новий афект.

У колі погляду цих красивих яскравих очей

I посміхається повітря навкруги,

I море підіймається й вітер,

I зробити небо інакшим світлом прикрашеним,

Тільки в мене вологі, сумні очі.

Звичайно, коли ти народилася

Так жорстоко й сміховинно

Народилася моя смерть.

Монтеверді використовує звукозображальність, щоб втілити особливо важливі слова. У першій половині він музично зображує рух природи: вводить мелізми та пульсуючі мотиви - для «повітря, що посміхається», хвилеподібні мелодичні лінії - для створення образу спокійного моря, та імітаційну висхідну лінію - для ясного неба.

У другій половині мадригалу акцент робиться на особистості героя. Використовується мінорна тональність, партія tепоге знижується й самотньо занурюється в тугу. В останньому куплеті (тт. 37-73) композитор використовує імітаційну поліфонію, щоб підкреслити парадоксальний зміст заключної фрази - день народження одного героя став днем смерті іншого («Звичайно, коли ти народилася, так жорстоко й сміховинно, народилася моя смерть»). Мадригал включає мотиви ламаного мінорного тризвуку, перехід з мінору в мажор як загальноприйнятий заключний акорд бароко.

Настрій змінюється на фразі «Тільки в мене вологі, сумні очі» (т. 37). Раптова зміна емоції та гармонії не випадкова, усе слідує за поетичним текстом. Далі К. Монтеверді повертається до основного емоційного тону, як це зробив поет: «Моя смерть народилася з твоєї жорстокості». Дисонанс тут сприймається як дуже різкий через його неочікуваність. Декламаційна мелодія 3 двома голосами на одній ноті раптово перетворюється на повільний ланцюг затримань.

Цей перехід від унісону до дисонансу завдяки руху однієї мелодії на тон або півтон - це улюблений прийом в цій книзі, і він завжди дивує через швидкий перехід від найбільш спокійного консонансу до одного 3 
найбільш жорстких співзвуч. Незважаючи на це, і в цьому, і в інших мадригалах після використання такого прийому як «знаряддя несподіванки» основний тон п'єси змушує епізод розширитися, i за рахунок повторень дисонуючих фраз втрачає свою жорсткість.

Про Четверту книгу мадригалів композитора пише Д. Арнольд: «Без сумніву, Монтеверді тепер пише музику більш для аристократичного слухача, ніж для аристократичного виконавця. Жодна група аматорів не зможе виконати цю музику правильно. Старі традиції мадригалів мертві як у мадригалах Джезуальдо, так і в монодії Флорентійської камерати» [10, с. 63].

Інтуїція Клаудіо Монтеверді, його знання того, де розмістити акценти та як знайти еквівалент внутрішньому змісту слів, надають Четвертій книзі мадригалів особливої вишуканості, яка формувалася протягом даного творчого періоду композитора.

Отже, від Першої до Четвертої книг мадригалів Клаудіо Монтеверді змінювалась тематика поетичних текстів: від пасторальної атмосфери Першої книги, теми природи у Другій, емоційно-напруженої образної сфери Третьої до переживання болю, страждань у Четвертій книзі. Розвивалися засоби втілення їх у музичній тканині: від поліфонічного викладу голосів до виразних мелодій у прозорій фактурі, в поєднанні 3 сучасними композиторові гармоніями.

1. Даньшина Н. В. Специфіка виконання ренесансної вокальної музики в умовах вітчизняної хорової практики : дис. ... канд. мистецтвознавства : 17.00.03/ Національна музична академія України ім. П. І. Чайковського. Київ, 2013. 202 с.

2. Жаркова В. Мадригали Клаудіо Монтеверді в контексті музичної культури його часу // Мистецтвознавчі записки : зб. наук. праць. Вип. 20. Київ, 2011. С. 3-9.

3. Игнатьева Н. С. Мадригалы мантуанских композиторов на тексты Верного пастуха Дж. Б. Гварини (к истории второй практики) : дисс. ... канд. искусствоведения : 17.00.02 / Московская государственная консерватория им. П. И. Чайковского. Москва, 2017. 348 с.

4. Конен В. Клаудио Монтеверди. Москва : Музыка, 1971. 334 с.

5. Молчанов А. Смысловая роль повтора в музыке // Вестник Московского государственного университета культуры и искусств. 2008. № 5. С. 284-286.

6. Назарова Н. Трансформация жанра мадригала в творчестве К. Монтеверди// Культура народов Причерноморья. 2014. № 277. С. 119-122.

7. Пєшкова В. «Altri canti d'amor tenero arciero» 3 «Восьмої книги» мадригалів Клаудіо Монтеверді: цілісність музичної композиції // Київське музикознавство : зб. статей. Вип. 57 : Культурологія та мистецтвознавство : До 150-річчя Київського інституту музики ім. Р. М. Глієра. Київ, 2018. С. 153-163.

8. Пешкова В. Мадригал К. Монтеверди «Hor che'l ciel e la terra» («Час, когда небо и земля»): особенности воплощения поэтического текста // Київське музикознавство : 3б. статей. Вип. 54. Київ, 2016. С. 79-85. 
9. Юнеева Е. А. Музыкальная культура Италии XVII-XVIII вв.: феномен барочной оперы : дисс. ... канд. исторических наук : 24.00.01. Волгоград, 2015. 197 с.

10. Arnold D. Monteverdi. 3rd ed. / revised by T. Carter. Oxford : Oxford University Press, 2005. 246 p. (Master Musicians Series).

11. Bianconi L. Music in the Seventeenth Century. Cambridge : Cambridge University Press, $1987.346 \mathrm{p}$.

12. Gallico C. Monteverdi : poesia musicale, teatro e musica sacra. Torino : G. Einaudi, 1979. 191 p.

13. Monteverdi C. Lettere, dediche, e prefazioni/edizione critica con note a cura di D. De’ Paoli. Roma : De Santis, 1973. 426 p.

14. Pryer A. Introduzione // Claudio Monteverdi : Sacrae Cantiunculae ; Madrigali Spirituali ; Canzonette a 3 Voci / edizione critica di Anthony Pryer. Cremona : Fondazione Claudio Monteverdi, 2012. P. 3-13. (Opera omnia : edizione nazionale / Claudio Monteverdi ; 1). URL: https://www.academia.edu/33728297/Claudio_Monteverdi_Sacrae_Cantiunculae_ Madrigali_Spirituali_Canzonette_a_3_Voci (access date: 05.01.2019).

15. Schrade L. Monteverdi : Creator of Modern Music. New York : Norton, 1950. 384 p.

16. Tomlinson G. Monteverdi and the End of the Renaissance. Oxford: Clarendon Press, $1987.280 \mathrm{p}$.

17. Whenham J., Wistreich R. The Cambridge companion to Monteverdi. Cambridge ; New York : Cambridge University Press, 2007. 358 p.

\section{References}

1. Danshyna, N. (2013). Specificity of performance of the renaissance vocal music in conditions of national choral practice. PhD thesis. Ukrainian National Tchaikovsky Academy of Music. Kyiv [in Ukrainian].

2. Zharkova, V. (2011). Madrigals by Claudio Monteverdi in the context of the musical culture of his time. Mystetstvoznavchi zapysky, 20, pp. 3-9 [in Ukrainian].

3. Ignatieva, N. (2017). Madrigals of Mantuan Composers for Texts of the Faithful Shepherd J. B. Guarini (on the history of the second practice). $\mathrm{PhD}$ thesis. Moscow State Tchaikovsky Conservatory. Moscow [in Russian].

4. Konen, V. (1971). Claudio Monteverdi. Moscow: Muzyka [in Russian].

5. Molchanov, A. (2008). Semantic role of replay in music. Vestnik Moskovskogo gosudarstvennogo universiteta kultury i iskusstv, 5, pp. 284-286 [in Russian].

6. Nazarova, N. (2014). The transformation of the madrigal genre in the work of C. Monteverdi. Kultura narodov Prichernomorya, 277, p. 119-122 [in Russian].

7. Pieshkova, V. (2018) "Altri canti d'amor tenero arciero» from the «Eighth Book» of madrigals by Claudio Monteverdi: the integrity of the musical composition. Kyivske muzykoznavstvo, 57, pp. 153-163 [in Ukrainian].

8. Pieshkova, V. (2016). C. Monteverdi's madrigal «Hor che'l ciel e la terra» («The time when heaven and earth»): features of the embodiment of the poetic text. Kyivske muzykoznavstvo, 54, pp. 79-85 [in Russian].

9. Yuneeva, E. (2015). Musical culture of Italy of the XVII - XVIII centuries: the phenomenon of baroque opera. $\mathrm{PhD}$ thesis. Volgograd State Medical University. Volgograd [in Russian].

10. Arnold, D. (2005). Monteverdi. 3rd ed. T. Carter (Ed.). Oxford: Oxford University Press [in English]. 
11. Bianconi, L. (1987). Music in the Seventeenth Century. Cambridge: Cambridge University Press [in English].

12. Gallico, C. (1979). Monteverdi: musical poetry, theater and sacred music. Torino: G. Einaudi [in Italian].

13. Monteverdi, C. (1973). Letters, dedications, and prefaces. D. De' Paoli (Ed.). Rome: De Santis [in Italian].

14. Pryer, A. (2012). Introduction. In: A. Pryer, ed. Claudio Monteverdi: Sacrae Cantiunculae; Madrigali Spirituali; Canzonette a 3 Voci, [online] Cremona: Fondazione Claudio Monteverdi, pp.3-13. Available at: https://www.academia.edu/33728297/Claudio_ Monteverdi_Sacrae_Cantiunculae_Madrigali_Spirituali_Canzonette_a_3_Voci [Accessed 05 January 2019] [in English].

15. Schrade, L. (1950). Monteverdi: Creator of Modern Music. New York: Norton [in English].

16. Tomlinson, G. (1987). Monteverdi and the End of the Renaissance. Oxford: Clarendon Press [in English].

17. Whenham, J., Wistreich, R. (2007). The Cambridge companion to Monteverdi. Cambridge; New York: Cambridge University Press [in English].

УДК 78.071.1 Холст:791

DOI: https://doi.org/10.33643/kmus.2019.59.11

Марина Гайдук,
аспірантка кафедри історії світової музики
Національної музичної академії Украӥни імені П. I. Чайковського
httрs://orcid.org/0000-0002-9399-5494
marishka.gayduk@gmail.com
Maryna Haiduk,
Postgraduate at the Department of History of World Music,
Ukrainian National Tchaikovsy Academy of Music
https://orcid.org/0000-0002-9399-5494
marishka.gayduk@gmail.com

\section{«МАРС» ГУСТАВА ХОЛСТА \\ ТА ОБРАЗНО-ІНТОНАЦЙНИЙ ТИПАЖ «СИЛ ЗЛА» У СУЧАСНОМУ КІНЕМАТОГРАФІ}

Англійський симфонізм доби модернізму - це глибинне, усталене в музичній культурі XX століття, самобутнє явище, дослідження якого є актуальним музикознавчим завданням. Mema публікації - виявити спільний образно-інтонаційний типаж у симфонічних композиціях Г. Холста, Х. Ціммера, Дж. Вільямса. За допомогою феноменологічного методологічного підxоду визначаються характеристики тематичного матеріалу обраних зразків музики. Компаративний метод сприяє виявленню рис подібності, які й формують спільний образно-інтонаційний типаж. Г. Холст, засвоївши досвід симфоністів-попередників, зумів 